\section{The heterogeneous nature of Fe delivery from melting icebergs}

\section{M.J. Hopwood ${ }^{1 *}$, C. Cantoni ${ }^{2}$}

\section{J.S. Clarke ${ }^{1}$, S. Cozzi ${ }^{2}$, E.P. Achterberg}

\begin{abstract} The micronutrient iron $(\mathrm{Fe})$ can be transported from marine terminating glaciers to the ocean by icebergs. There are however few observations of iceberg Fe content, and the flux of Fe from icebergs to the offshore surface ocean is poorly constrained. Here we report the dissolved Fe $(\mathrm{DFe})$, total dissolvable $\mathrm{Fe}(\mathrm{TdFe})$ and ascorbic acid extractable Fe (FeAsc) sediment content of icebergs from Kongsfjorden, Svalbard. The concentrations of DFe (range $0.63 \mathrm{nM}-536 \mathrm{nM}$, mean $37 \mathrm{nM}$, median $6.5 \mathrm{nM}$ ) and TdFe (range $46 \mathrm{nM}-57 \mu \mathrm{M}$, mean $3.6 \mu \mathrm{M}$, median $144 \mathrm{nM}$ ) both demonstrated highly heterogeneous distributions and there was no significant correlation between these two fractions. FeAsc (range 0.0042 to $0.12 \mathrm{wt}$. \%) was low compared to both previous measurements in Kongsfjorden and to current estimates of the global mean. FeAsc content per volume ice did however, as expected, show a significant relationship with sediment loading (which ranged from $<0.1-234 \mathrm{~g} \mathrm{~L}^{-1}$ of meltwater). In the Arctic, icebergs lose their sediment load faster than ice volume due to the rapid loss of basal ice after calving. We therefore suggest that the loss of basal ice is a potent mechanism for the reduction of mean TdFe and FeAsc per volume of iceberg. Delivery of TdFe and FeAsc to the ocean is thereby biased towards coastal waters where, in Kongsfjorden, DFe $(18 \pm 17 \mathrm{nM})$ and TdFe (mean $8.1 \mu \mathrm{M}$, median $3.7 \mu \mathrm{M}$ ) concentrations were already elevated.
\end{abstract}

Received 27 September 2016 | Accepted 25 April 2017 | Published 7 June 2017

\section{Introduction}

Icebergs contain higher Fe concentrations than seawater, both in the dissolved $(<0.2 \mu \mathrm{m})$ (Martin et al., 1990; De Baar et al., 1995; Loscher et al., 1997) and particulate $(>0.2 \mu \mathrm{m})$ phases (Hart, 1934; Lin et al., 2011; Shaw et al., 2011). Icebergs should thus constitute a source of the micronutrient Fe to offshore polar waters (Raiswell et al., 2008). As the rate of iceberg calving in polar seas oscillates on glacial to inter-glacial timescales (Bond et al., 1992), and recent climate change has

1. GEOMAR, Helmholtz Centre for Ocean Research, 24148 Kiel, Germany

* Corresponding author (email: mhopwood@geomar.de)

2. CNR-ISMAR, Marine Science Institute, 34149 Trieste, Italy increased the discharge of calved ice volume from both the Antarctic (Paolo et al. 2015) and Greenlandic (Bamber et al., 2012) ice sheets, Fe delivery from icebergs may also change. Particularly in the Southern Ocean, where DFe deficiency extensively limits primary production (Martin et al., 1990, 1991; Moore et al., 2013), and icebergs cause chemical and biological enrichment of surrounding waters (Smith Jr. et al., 2007; Schwarz and Schodlok, 2009; Smith et al., 2011), a change in iceberg Fe supply could significantly affect marine primary productivity. Yet there remain large uncertainties concerning the magnitude of iceberg Fe supply and its effect(s) on marine ecosystems. For example, calculated phytoplankton Fe utilisation is considerably less than present estimates of iceberg Fe supply to the Weddell Sea (Boyd et al., 2012). The reason for this is unclear, yet it demonstrates the difficulty in isolating the contribution of icebergs to the marine Fe cycle.

Observations of DFe concentrations in iceberg meltwater are sparse, but the available data does suggest a heterogeneous distribution, with DFe ranging 4-600 nM in Antarctic (Lin et al 2011) and 3-300 nM in Greenlandic (Hopwood et al., 2016) iceberg melt. The distribution of particulate Fe (which includes FeAsc) is also expected to be heterogeneous due to the presence of embedded sediment rich layers that account for only a small fraction of total iceberg volume (Lin et al., 2011; Raiswell, 2011; Raiswell et al., 2016). Whilst TdFe data for icebergs is sparse, iceberg FeAsc content has previously been estimated in multiple catchments worldwide (Raiswell et al., 2016) producing a mean global content of 2.7-17 $\mu \mathrm{M}$. However, FeAsc content and offshore iceberg FeAsc fluxes are normally calculated using a mean sediment loading $\left(0.5 \mathrm{~g} \mathrm{~L}^{-1}\right.$ is widely used as outlined in Raiswell et al. (2016)) with considerable uncertainty generally acknowledged in this value. Here we combine the analysis of DFe, TdFe, FeAsc and iceberg sediment load in order to provide a well constrained assessment of iceberg-Fe content within a single catchment.

\section{Methods}

A FeAsc dataset was compiled for icebergs in Kongsfjorden with visible embedded or surface sediment sampled from small boats in July 2015 and August 2016. Sediment from pro-glacial streambeds in the catchment, embedded sediment from Kongsvegen glacier surface, and embedded sediment $100 \mathrm{~m}$ inside an ice crevasse (on Midtre Lovénbreen glacier) was also collected (Fig. 1) for comparative purposes. FeAsc leaches were conducted on wet sediment as per Raiswell et al. (2010), with leached Fe determined by measuring absorbance $(\lambda=562 \mathrm{~nm})$ before and after the addition of ferrozine (as detailed in Supplementary Information Methods).

Separately, ice samples (1-2 kg) were randomly collected from small boats (July 2015). The meltwater was acidified to $\mathrm{pH}<2$. After storage for 12 months, DFe and TdFe were measured by inductively coupled plasma mass spectroscopy (further details in Supplementary Information Methods). 


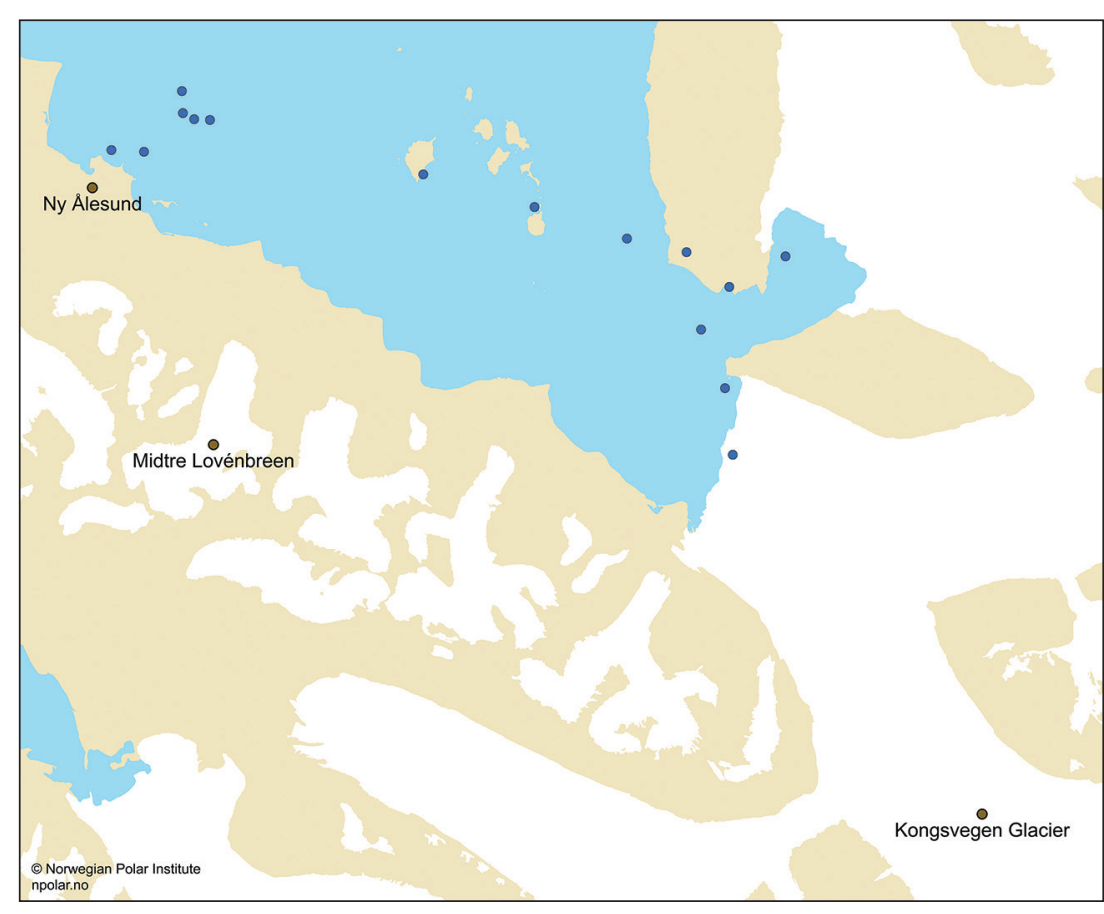

Figure 1 Surface fjord sample locations in Kongsfjorden.

\section{Results}

The FeAsc concentration is reported for 116 different sediment samples (Table S-2) including 58 iceberg samples collected from ice with visible embedded sediment. FeAsc ranged from 0.0042 to 0.12 wt. \% in iceberg embedded sediment (Fig. 2). Ice sediment content ranged from $<0.1$ to $234 \mathrm{~g} \mathrm{~L}^{-1}$ of meltwater, close to the $0.2-200 \mathrm{~g} \mathrm{~L}^{-1}$ range previously reported in Svalbard by Dowdeswell and Dowdeswell (1989). Combining FeAsc (wt. \%) and sediment load ( $\mathrm{g} \mathrm{L}^{-1}$ of melted ice) produced a median FeAsc ice content of $2.5 \mu \mathrm{M}$. Given that our sampling strategy was to target sediment-rich ice, this should thereby be an over-estimate of median iceberg FeAsc content ( $\mathrm{L}^{-1}$ of melted ice) in Kongsfjorden.

The DFe and TdFe concentrations are reported in parallel for 28 randomly collected iceberg samples (Table S-4). TdFe ranged from $46 \mathrm{nM}$ to $57 \mu \mathrm{M}$ (mean $3.6 \mathrm{uM}$, median $144 \mathrm{nM}$ ) and the range of $0.63 \mathrm{nM}-536 \mathrm{nM}$ for DFe was similarly broad (mean $37 \mathrm{nM}$, median $6.5 \mathrm{nM}$ ). There was no significant correlation between particulate Fe (TdFe minus DFe) and DFe in these samples (Fig. 3), suggesting that DFe was not specifically associated with sediment laden ice. For comparison, DFe in surface fjord waters averaged $18 \pm 17 \mathrm{nM}$ (15 surface stations, Fig. 1) and TdFe ranged widely from 1.1 to $52 \mu \mathrm{M}$ (mean $8.1 \mu \mathrm{M}$, median $3.7 \mu \mathrm{M}$ ) (Table S-3).

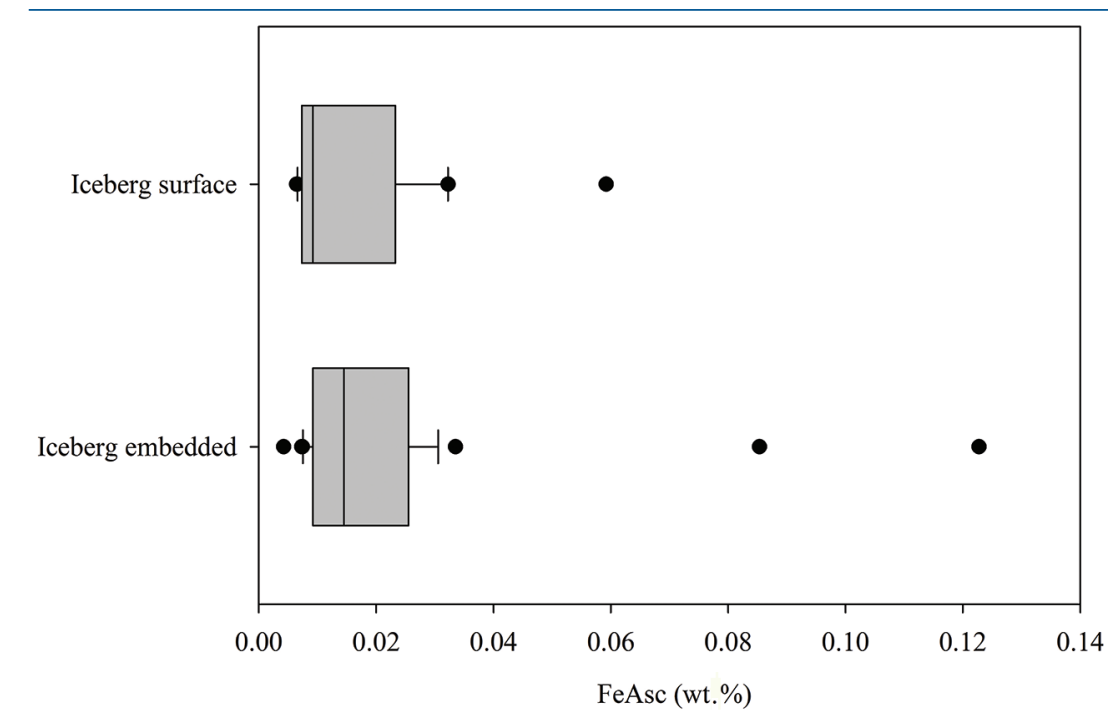

Figure 2 Median FeAsc (wt. \%) with 25/75 th (boxes) and 10/90 th (whiskers) percentiles (outliers also shown) for iceberg embedded $(n=34)$ and iceberg surface $(n=20)$ sediment.

\section{Discussion}

As has been demonstrated in this study and elsewhere (e.g. Markussen et al 2016), surface waters in stratified, glaciated fjords can exhibit extremely high TdFe concentrations due to the presence of glacially derived particle plumes. TdFe concentrations in surface waters of Kongsfjorden (mean $8.1 \mu \mathrm{M}$, median $3.7 \mu \mathrm{M})$ exceeded those in icebergs $(3.6 \mu \mathrm{M}$ and $144 \mathrm{nM}$, respectively). In the Arctic, a large fraction of iceberg melt occurs in these inshore, high TdFe waters before icebergs are able to deliver Fe to the offshore environment. Accounting for this near-shore loss in flux calculations for iceberg derived Fe supply to the open ocean is difficult. In two Greenlandic catchments, Ilulissat Fiord and Sermilik Fiord, overall in-fjord iceberg volume losses were estimated to be $>50 \%$ (Enderlin et al., 2016), tentatively supporting the $50 \%$ inshore iceberg volume loss used to estimate offshore FeAsc fluxes by Raiswell et al. (2016). However this assumes that changes in total iceberg Fe content are directly proportional to changes in total ice volume. 
All measured Fe phases (DFe, TdFe and FeAsc) in Kongsfjorden were very heterogeneously distributed within the ice. For TdFe and FeAsc (but not DFe, Fig. 3), this can specifically be attributed to the heterogeneous distribution of ice embedded sediment. In the Arctic, iceberg-borne sediment is known to be lost from icebergs faster than ice volume (Mugford and Dowdeswell, 2010) due to its association with basal ice. Thus we expect that the mean TdFe content per volume of an iceberg should decline with time after calving. A model for Kangerdlugssuaq Fjord (Greenland) shows that whilst icebergs lose 20-30\% ice volume within this fjord, the corresponding in-fjord sediment loss is 70-85 $\%$ (Mugford and Dowdeswell, 2010). Only a relatively small iceberg volume loss $(<20 \%)$ is thereby likely required for the majority of TdFe content to be lost from icebergs. In Kongsfjorden, where summer melting of calved ice is quite rapid due to relatively warm surface seawater $\left(4-5{ }^{\circ} \mathrm{C}\right.$ throughout July-August 2016), the post-calving age of an iceberg is therefore likely a critical factor in determining its TdFe content. Sediment loss should also affect mean FeAsc content in the same way, however FeAsc losses may be offset from TdFe losses if significant processing of surface sediment occurs on the timescale of iceberg Fe delivery (Raiswell et al., 2016).

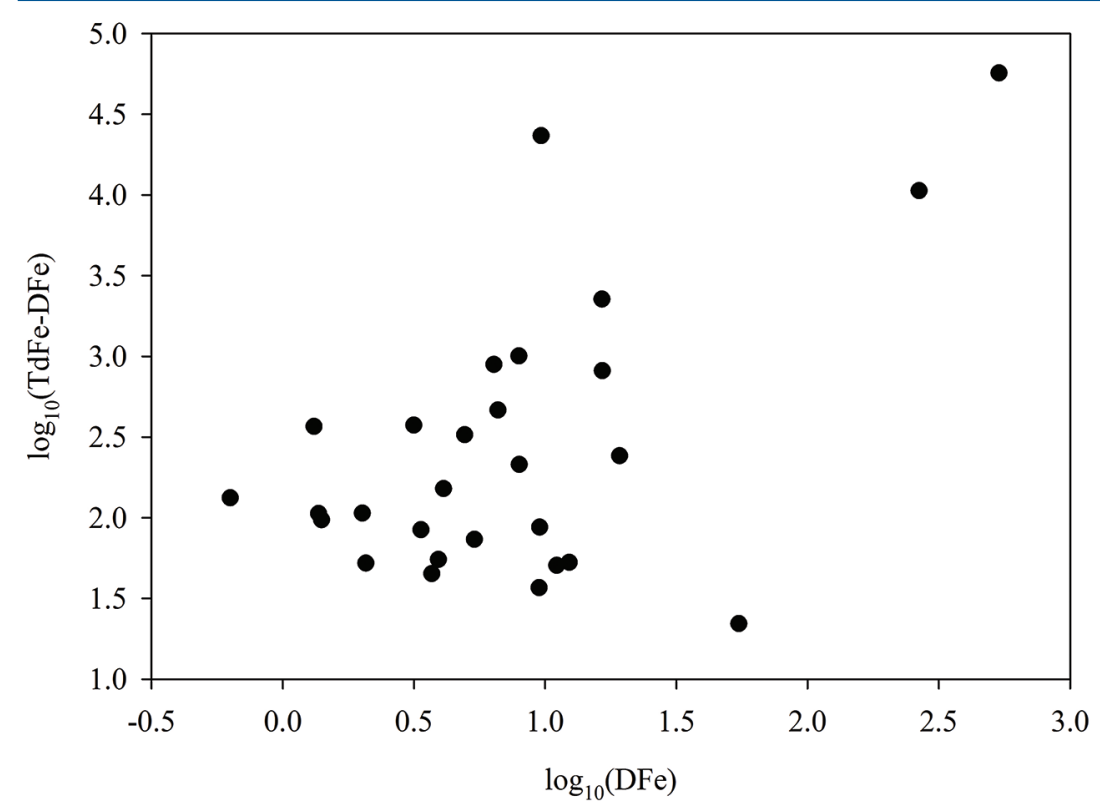

Figure 3 DFe and TdFe (both $\mathrm{nM}$, plotted as $\log _{10}$, TdFe shown minus DFe) for 28 discrete iceberg samples showed no clear relationship.
In Kongsfjorden, Raiswell et al. (2016) reported a FeAsc range of $0.016-0.37$ wt. \% $(n=14)$, with a mean of 0.14 wt. \% and median of 0.092 wt. \%; equivalent to $1.4-33 \mu \mathrm{M}, 12 \mu \mathrm{M}$ and $8.2 \mu \mathrm{M}$, respectively when using the suggested mean sediment loading of $0.5 \mathrm{~g} \mathrm{~L}^{-1}$. Comparing our data both as wt. \% and as a $u \mathrm{M}$ concentration (calculated using measured sediment loading for each sample, range $0.1-234 \mathrm{~g} \mathrm{~L}^{-1}$, Table S-2), our FeAsc (wt. \%) is consistently lower. Yet our mean FeAsc per volume is much higher $(51 \mu \mathrm{M})$, because our measured sediment loadings were often greater than the assumed mean of $0.5 \mathrm{~g} \mathrm{~L}^{-1}$. These differences generally highlight the very high spatial variability in iceberg sediment load and thus TdFe and FeAsc content even within a single fjord.

Table 1 Comparing data for Kongsfjorden from this and prior work suggests a critical difference in both FeAsc (wt. \%) and in the scaling of FeAsc to iceberg sediment load ( $\mathrm{L}^{-1}$ of ice melt). *The suggested $0.5 \mathrm{~g} \mathrm{~L}^{-1}$ sediment loading is used for data from Raiswell et al. (2016). ** For our study measured sediment loadings were used for each sample. As sediment-rich ice was specifically targeted, the calculated mean/median should be over-estimates.

\begin{tabular}{|l|c|c|c|c|}
\hline \multirow{2}{*}{ FeAsc / wt. \% } & & a This study & b Raiswell et al. (2016) & a/b \% \\
\cline { 2 - 5 } & Mean & 0.021 & 0.14 & 16 \\
\hline \multirow{2}{*}{$\begin{array}{l}\text { FeAsc / } \mu \mathrm{M} \text { (per litre } \\
\text { of ice melt)* }\end{array}$} & 0.015 & 0.092 & 17 \\
\cline { 2 - 5 } & Mean & $<59 * *$ & 12 & 480 \\
\hline
\end{tabular}

Some methodological differences between this study and previous work could be important for the difference in FeAsc (wt. \%) (Table 1). In our study, the sediment was not sieved to remove anomalous large particles. Yet a relatively large sub-sample mass was used with good reproducibility demonstrated. For glacial flour particles of $<1 \mathrm{~mm}$, it has previously been demonstrated that the change in FeAsc (wt. \%) with particle size is not pronounced (Hopwood et al., 2014; Raiswell et al., 2016), but this may not be the case for larger particles. Moreover, in this study sediment was processed in Svalbard with no prolonged storage between collection and analysis. Whilst dried sediment exhibits a rapid decline in FeAsc wt. \% (Raiswell et al., 2010), it is not clear how storage of ice or wet sediments affects FeAsc.

Furthermore, there are the critical issues of heterogeneity and of the nonlinearity between iceberg sediment and iceberg volume losses. In-fjord iceberg volume loss should correspond to a disproportionately high loss of iceberg embedded sediment (Mugford and Dowdeswell, 2010), and thereby also FeAsc and TdFe. There are no quantitative measures of iceberg age or volume loss for our dataset and the residence time of ice in Kongsfjorden is strongly affected by meteorological conditions and thus subject to high short-term variability. Nonetheless, a difference in the post-calving age of ice sampled between different datasets could correspond to large shifts in iceberg FeAsc and TdFe content. Increased iceberg age would be expected to correspond to lower mean sediment load, and thereby lower TdFe and FeAsc per volume. A reduction in basal 
sediment load could also explain a difference in FeAsc (wt. \%) content if FeAsc (wt. \%) is enriched in basal ice compared to non-basal ice. FeAsc $\left(\mu \mathrm{mol} \mathrm{L}{ }^{-1}\right)$ is correlated with sediment load (Fig. 4), but assessing whether changes in sediment load affect FeAsc (wt. \%) is complicated by the lack of any parameter to account for the post-calving age of ice and by the highly variable bedrock composition across Kongsfjorden (see for example Hjelle, 1993).

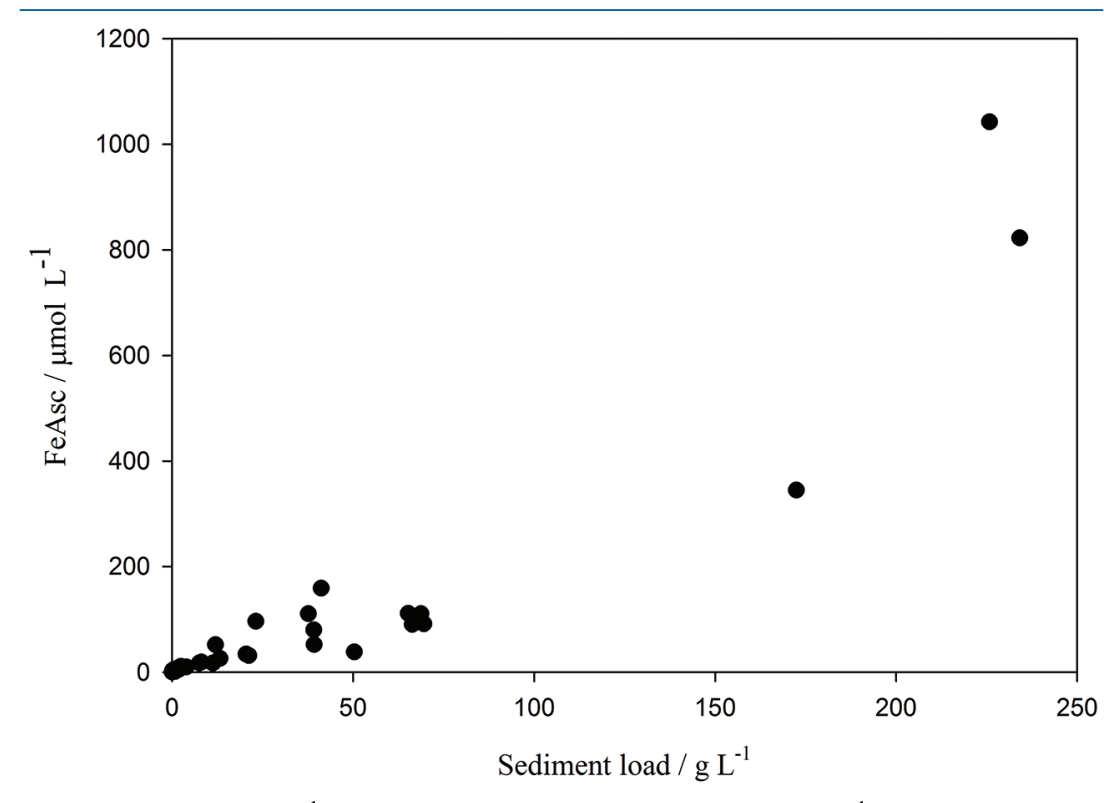

Figure 4 FeAsc (umol L-1 melted ice) increased with sediment load ( $\mathrm{L} \mathrm{L}^{-1}$ melted ice), but it is unclear if the relationship remains linear at high $\left(>50 \mathrm{~g} \mathrm{~L}^{-1}\right)$ loadings.

\section{Conclusions}

Whilst median DFe (6.5 nM) and TdFe (144 nM) concentrations in Kongsfjorden were within the range of concentrations reported elsewhere globally, the median FeAsc concentration $(2.5 \mu \mathrm{M})$ measured was considerably lower than that reported previously in Kongsfjorden, and compared to present estimates of the global mean, despite the very high sediment loadings observed $\left(<0.1-234 \mathrm{~g} \mathrm{~L}^{-1}\right)$. Generally in the Arctic, a sharp decline in the mean FeAsc and TdFe per volume of meltwater from icebergs with time after calving would be expected due to the preferential loss of iceberg basal ice, as modelled by Mugford and Dowdeswell (2010). Iceberg derived fluxes of TdFe and FeAsc are thereby biased towards delivery in near-shore waters and offshore fluxes are likely much less than if TdFe and FeAsc were homogeneously distributed throughout icebergs.

\section{Glossary}

' $\mathrm{Fe}^{\prime}$ refers to all iron phases.

'DFe', dissolved $\mathrm{Fe}$, refers to all Fe phases $<0.2 \mu \mathrm{m}$.

'FeAsc' is the ferrihydrite content of sediment, defined by Raiswell et al. (2010). 'TdFe' is all Fe soluble at $\mathrm{pH}<2$, inclusive of DFe and should also include any FeAsc present in unfiltered meltwater.

\section{Acknowledgements}

Financial aid from the European Commission (OCEAN-CERTAIN, FP7ENV-2013-6.1-1; no: 603773) is gratefully acknowledged. 2016 fieldwork was conducted during the CNR Dirigibilite Italia hosted project ' $\mathrm{pH}$ in Svalbard'.

Editor: Liane G. Benning

\section{Additional Information}

Supplementary Information accompanies this letter at www.geochemicalperspectivesletters.org/article1723

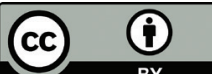

This work is distributed under the Creative Commons Attribution 4.0 License, which permits unrestricted use, distribution, and reproduction in any medium, provided the origina author and source are credited. Additional information is available at http://www. geochemicalperspectivesletters.org/copyright-and-permissions.

Cite this letter as: Hopwood, M.J., Cantoni, C., Clarke, J.S., Cozzi, S., Achterberg, E.P. (2017) The heterogeneous nature of Fe delivery from melting icebergs. Geochem. Persp. Let. 3, 200-209.

\section{References}

Bamber, J., van den Broeke, M., Ettema, J., Lenaerts, J., Rignot, E. (2012) Recent large increases in freshwater fluxes from Greenland into the North Atlantic. Geophysical Research Letters 39, L19501, doi:10.1029/2012g1052552.

Bond, G., HeinRich, H., BRoecker, W.S., Labeyrie, L., MCMANuS, J.F., ANDReWS, J.T., HUON, S., Jantschik, R., Clasen, S., Simet, C., Tedesco, K., Klas, M., Bonani, G., Ivy, S. (1992) Evidence for massive discharges of icebergs into the North Atlantic ocean during the last glacial period, Nature 360, 245-249.

Boyd, P.W., ArRigO, K.R., StrZePeK, R., VAn DijKen, G.L. (2012) Mapping phytoplankton iron utilization: Insights into Southern Ocean supply mechanisms. Journal Geophysical Research: utilization: Insights into Southern Ocen
Oceans 117, doi:10.1029/2011JC007726. 
De BAar, H.J.W., De Jong, J.T.M., BAKKeR, D.C.E., Loscher, B.M., Veth, C., BATHMann, U., SMETACEK, V. (1995) Importance of iron for plankton blooms and carbon dioxide drawdown in the Southern Ocean. Nature 373, 412-415.

DOWDESWELL, J.A., DOWDESWELL, E.K. (1989) Debris in Icebergs and Rates of Glaci-Marine Sedimentation: Observations from Spitsbergen and a Simple Model. The Journal of Geology 97, $221-231$.

Enderlin, E.M., Hamilton, G.S., Straneo, F., Sutherland, D.A. (2016) Iceberg meltwater fluxes dominate the freshwater budget in Greenland's iceberg-congested glacial fjords. Geophysical Research Letters 43, 11287-11294.

HART, T.J. (1934) Discovery Reports. Discovery Reports 8, 1-268.

HJElLe, A. (1993) The geology of Svalbard: Oslo. Polarhåndbok nr. 6. Norsk Polarinstitutt, Oslo.

HopWOOD, M.J., Statham, P.J., TRAnTER, M., WAdHAM, J.L. (2014) Glacial flours as a potential source of $\mathrm{Fe}(\mathrm{II})$ and $\mathrm{Fe}(\mathrm{III})$ to polar waters. Biogeochemistry 118, 443-452.

Hopwood, M.J., Connelly, D.P., Arendt, K.E., JuUl-Pedersen, T., Stinchlombe, M., Meire, L., EsPOSITO, M., KRISHNA, R. (2016) Seasonal changes in Fe along a glaciated Greenlandic fjord. Frontiers in Earth Sciences 4, doi:10.3389/feart.2016.00015

Lin, H., Rauschenberg, S., Hexel, C.R., Shaw, T.J., Twining, B.S. (2011) Free-drifting icebergs as sources of iron to the Weddell Sea. Deep Sea Research Part II: Topical Studies in Oceanography $58,1392-1406$.

Loscher, B.M., De BaAr, H.J.W., De Jong, J.T.M., Veth, C., Dehairs, F. (1997) The distribution of Fe in the Antarctic Circumpolar Current. Deep Sea Research Part II: Topical Studies in Oceanography 44, 143-187.

Markussen, T.N., Elberling, B., Winter, C., Andersen, T.J. (2016) Flocculated meltwater particles control Arctic land-sea fluxes of labile iron. Scientific Reports 6, 24033.

Martin, J.H., Gordon, R.M., FitZwATER, S.E. (1990) Iron in Antarctic waters. Nature 345, 156-158

Martin, J.H., Gordon, R.M., FitZwater, S.E. (1991) The case for iron. Limnology and Oceanography 36, 1793-1802.

Moore, C.M., Mills, M.M., Arrigo, K.R., Berman-Frank, I., Bopp, L., Boyd, P.W. Galbraith, E.D., Geider, R.J., Guieu, C., Jaccard, S.L., Jickells, T.D., La Roche, J., Lenton, T.M., Mahowald, N.M., Maranon, E., Marinov, I., Moore, J.K., NaKatsuka, T., Oschlies, A., Saito, M.A., Thingstad, T.F., TsudA, A., UlloA, O. (2013) Processes and patterns of oceanic nutrient limitation. Nature Geoscience 6, 701-710.

Mugford, R.I., DOWDESWELL, J.A. (2010) Modeling iceberg-rafted sedimentation in high-latitude fjord environments. Journal of Geophysical Research: Earth Surface 115, doi:10.1029/2009JF001564.

PAolo, F.S., Fricker, H.A., PADMAn, L. (2015) Volume loss from Antarctic ice shelves is accelerating. Science 348, 327-331.

RAISWELL, R. (2011) Iceberg-hosted nanoparticulate Fe in the Southern Ocean: Mineralogy, origin, dissolution kinetics and source of bioavailable Fe. Deep Sea Research Part II: Topical Studies in Oceanography 58, 1364-1375.

Raiswell, R., Benning, L.G., Tranter, M., Tulaczyk, S. (2008) Bioavailable iron in the Southern Ocean: the significance of the iceberg conveyor belt. Geochemical Transactions 9 , doi:10.1186/1467-4866-9-7.

RAISWELL, R., VU, H.P., BrinZA, L., BenNing, L.G. (2010) The determination of labile Fe in ferrihydrite by ascorbic acid extraction: Methodology, dissolution kinetics and loss of solubility with age and de-watering. Chemical Geology 278, 70-79.

Raiswell, R., Hawkings, J.R., Benning, L.G., BaKeR, A.R., Death, R., Albani, S., Mahowald N., KROM, M.D., POULTON, S.W., WADHAM, J., TRANTER, M. (2016) Potentially bioavailable iron delivery by iceberg-hosted sediments and atmospheric dust to the polar oceans. Biogeosciences 13, 3887-3900.
SCHWARZ, J.N., SCHODLOK, M.P. (2009) Impact of drifting icebergs on surface phytoplankton biomass in the Southern Ocean: Ocean colour remote sensing and in situ iceberg tracking. Deep Sea Research Part I: Oceanographic Research Papers 56, 1727-1741.

ShaW, T.J., Raiswell, R., HeXel, C.R., Vu, H.P., Moore, W.S., Dudgeon, R., SMith JR., K.L. (2011) Input, composition, and potential impact of terrigenous material from free-drifting icebergs in the Weddell Sea. Deep Sea Research Part II: Topical Studies in Oceanography 58, 1376-1383.

Smith, K.L., Sherman, A.D., Shaw, T.J., Murray, A.E., Vernet, M., Cefarelli, A.O. (2011) Carbon export associated with free-drifting icebergs in the Southern Ocean. Deep Sea Research Part II: Topical Studies in Oceanography 58, 1485-1496.

Smith JR., K.L., Robison, B.H., Helly, J.J., Kaufmann, R.S., Ruhl, H.A., Shaw, T.J., Twining, B.S., VERNET, M. (2007) Free-drifting icebergs: Hot spots of chemical and biological enrichment in the Weddell Sea. Science 317, 478-482. 